\title{
ORGANIC AGRICULTURE IN THE DEVELOPMENT OF A GREEN ECONOMY
}

\author{
Larisa Jovanovic ${ }^{1}$ \\ Dragan Živković ${ }^{2}$ \\ Mario Lukinovic ${ }^{3}$ \\ Milan Jankovic ${ }^{4}$
}

DOI: https://doi.org/10.31410/ITEMA.2019.215

\begin{abstract}
Sustainable development is a modern concept of economic development, which enables longterm economic growth rates to be achieved with better utilization of scarce natural resources and a better quality of life for the population to preserve the environment and reduce social inequalities. Care for the quality and way of life of the population integrated into this concept takes into account the needs in the context of intense globalization and fast-growing markets of present and future generations.

Among the economic activities, it is necessary to identify those that contribute most to the economic growth and sustainable development in terms of development opportunities. Considering that the Republic of Serbia occupies a favorable geographical position, has significant natural resources and a good workforce, agriculture stands out as one of the economic activities that significantly contribute to economic growth, with recognizable development potentials.

Organic production makes a significant contribution to achieving the goals of a green economy and green growth. Thanks to well-defined principles and standards, as well as a certification system, its positive impact on the health and life of all living things, the environment and natural resources is enabled. Both of these concepts are based on the same principles and offer numerous opportunities for improving the standard of living, developing underdeveloped countries and achieving sustainable development. In European countries, organic production is a model for sustainable rural development.

The intention of this paper is to investigate the possibilities and necessary incentive measures for the sustainable development of organic agriculture in the Republic of Serbia and compare the organic food production growth in European countries and in Serbia.
\end{abstract}

Keywords: Organic Agriculture, Agroecology, Green Economy, Organic Farming, Sustainable Rural Development, European Union, Republic of Serbia.

\section{INTRODUCTION}

$\mathrm{U}^{\mathrm{n}}$ nlike conventional agricultural production, organic farming is designed to meet the demands of quality food, human, animal and ecosystem health.

The concept of organic agriculture is closely related to the concept of green economy and has a positive impact on the achievement of its basic goals in the sector of healthy food production and environmental protection. On the other hand, the green economy creates the conditions for the application and development of organic agriculture.

\footnotetext{
University ALFA BK, Palmira Toljatija 3, Belgrade, Serbia

University ALFA BK, Palmira Toljatija 3, Belgrade, Serbia

University Union, Faculty of Law, Maršala Tolbuhina 36, Belgrade, Serbia

Faculty of Business Studies and Law, Jurija Gagarina 149a, Belgrade, Serbia
} 
Based on international agreements, organic farming and processing of organic products are defined as a management system based on the standards of the International Federation of Organic Agriculture Movements (IFOAM), national and local laws, regulations and guidelines for producers and their associations, which, with the support of the community and society as a whole, achieve common goals:

- protection of land and water resources,

- prevention of adverse effects on ecosystem health and human health,

- increasing biodiversity, and

- production of high quality and health food (IFOAM, 2019).

The main support for organic plant production is organic fertilizers such as: solid and liquid manure, fallow, various types of compost, thirties, plants intended for vegetable fertilization, pomas, sawdust, molasses, seaweed, and the use of some fertilizers is allowed; mineral origin powder of rocks, calcium and magnesium fertilizers, calcium algae, gypsum, crude phosphates, bone meal, etc. In addition to these fertilizers, the use of microbiological preparations is very significant.

The Republic of Serbia lags significantly behind the EU countries in the organic food sector.

Organic farming was developed to solve the problems caused by conventional methods in food production. These problems are related to soil erosion and degradation, pollution of surface waters and ecosystems. Organic agriculture causes less damage to the environment, human health and ecosystems for the following reasons:

- chemical pesticides and fertilizers are not used, thus eliminating risks to human health and environmental pollution,

- care for ecosystem health and biodiversity conservation is achieved through the maintenance of biological cycles,

- nutrient recycling and land restoration reduce the risk of pollution in the surrounding territories,

- recovery of soil through winter by using winter crops or plants that cover the soil, thereby improving soil quality, reducing the risk of erosion, degradation and compaction.

- Pest control is performed using biological, selective or mechanical methods and involves increasing the population of beneficial insects and enhancing biodiversity.

Research shows that organic products contain 50\% more vitamins, minerals, enzymes and other micronutrient components than conventional products. Also, organic products are the only guarantee that no genetically modified food is introduced into humans and animals.

According to the definition of FAO (Food and Agriculture Organization) and WHO (World Health Organization), organic farming uses production processes in accordance with the principles of sustainable rural development with the use of indigenous resources and recycling, thereby achieving complex farm with crop and livestock production. As the basic idea of organic production is based on the thesis that exploitation should be adapted to natural conditions and enable normal habitat recovery, organic farming is also called self-sustaining. Organic farming is an attempt to identify methods that should enable organic food production while reducing the negative impacts of intensive agricultural production on ecosystems.

Transformation of conventional agriculture into organic farming becomes crucial for achieving green economy goals (Janković, Jovanović, 2018) 


\section{STRATEGIES OF EUROPEAN COUNTRIES IN ORGANIC AGRICULTURAL DEVELOPMENT}

The experience of economically developed European countries shows that advances in organic food production have come from government subsidies, which stimulate organic farming.

In addition, it should be underlined that the production of milk and meat in developed countries has reached such a level that the state stimulates the reduction of production of these basic products as the needs of the population are encountered. Accent is placed on preserving a healthy environment because animals are known to be major pollutants of ecosystems, especially land, as their excrements contain a large amount of undigested matters and drugs that disrupt the balance of the soil, and it is worryingly endangered.

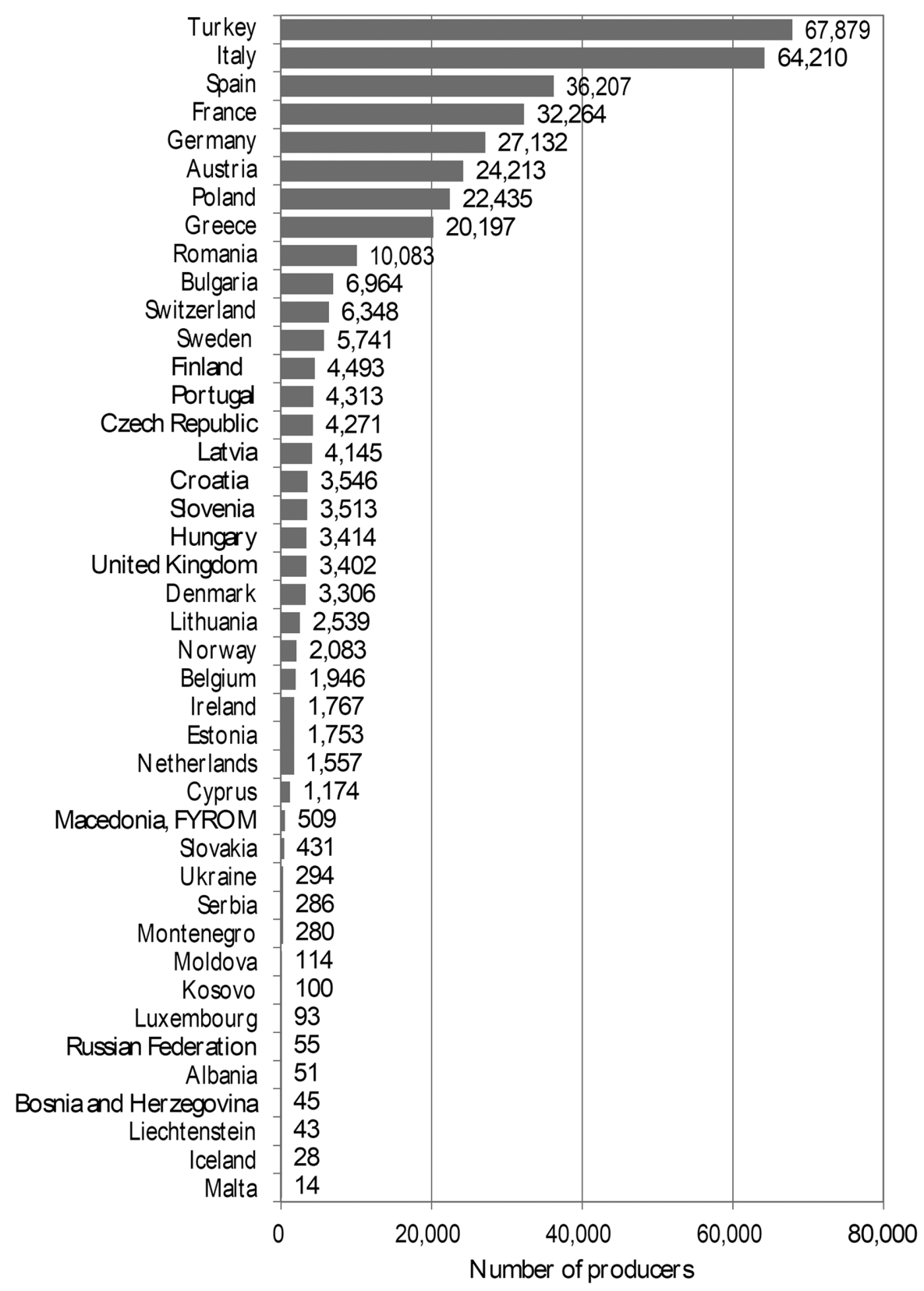

Figure 1 - Numbers of organic producers in Europe by country 2016

Source: FiBL-AMI survey 2018 based on national data sources and Eurostat. 
Animals create 130 times more waste products than humans. All modern biotechnology (production of enzymes, probiotics, chelating forms of microelements, organic selenium and chromium, oligosaccharides, etc.) is realized in order to maximize the use of nutrients in the organism and to eliminate undigested food from the environment.

In this sense, the aim of the European countries in the future is to reduce commercial production and to accelerate the production of quality seed material in both crop production and genetic material of the tested animals' throats selected for high production. High quality seed material of plant and animal origin has been obtained by the development of molecular biology and genetic engineering, all for the sake of making big profits, and is a sublimated knowledge that needs to be valorized through this profit. More than $45 \%$ of organic production in the European Union consists of grasslands and meadows for organic livestock production.

\subsection{Organic producers and importers}

There were more than 370,000 organic producers in Europe in 2016 (FiBL - AMI survey, 2018). The countries with the largest number of producers were Turkey (almost 68,000) and Italy (more than 64,000). Spain, France, and Germany had only half of the producers that Turkey and Italy had. Next countries were Austria, Poland and Greece. Romania, Bulgaria, Switzerland, Sweden, Finland and Portugal had significantly smaller number of producers. North Macedonia, Slovakia, Ukraine, Serbia and Montenegro had about 10 to 15 times fewer organic food producers than Italia and Spain (see Fig. 1).

Compared to the growth in 2015, the increase in numbers of producers was higher $(+7$ percent) in Europe. Over the decade 2007-2016, the number of producers in Europe increased by 76 percent.

Figure 2 presented the number of processors and importers. This number increased in almost all European countries in 2016. In Europe, there were about 66,000 processors. The country with the largest number of processors is Italy (26\%), and the country with the most importers is Germany (FiBL - AMI survey, 2018).
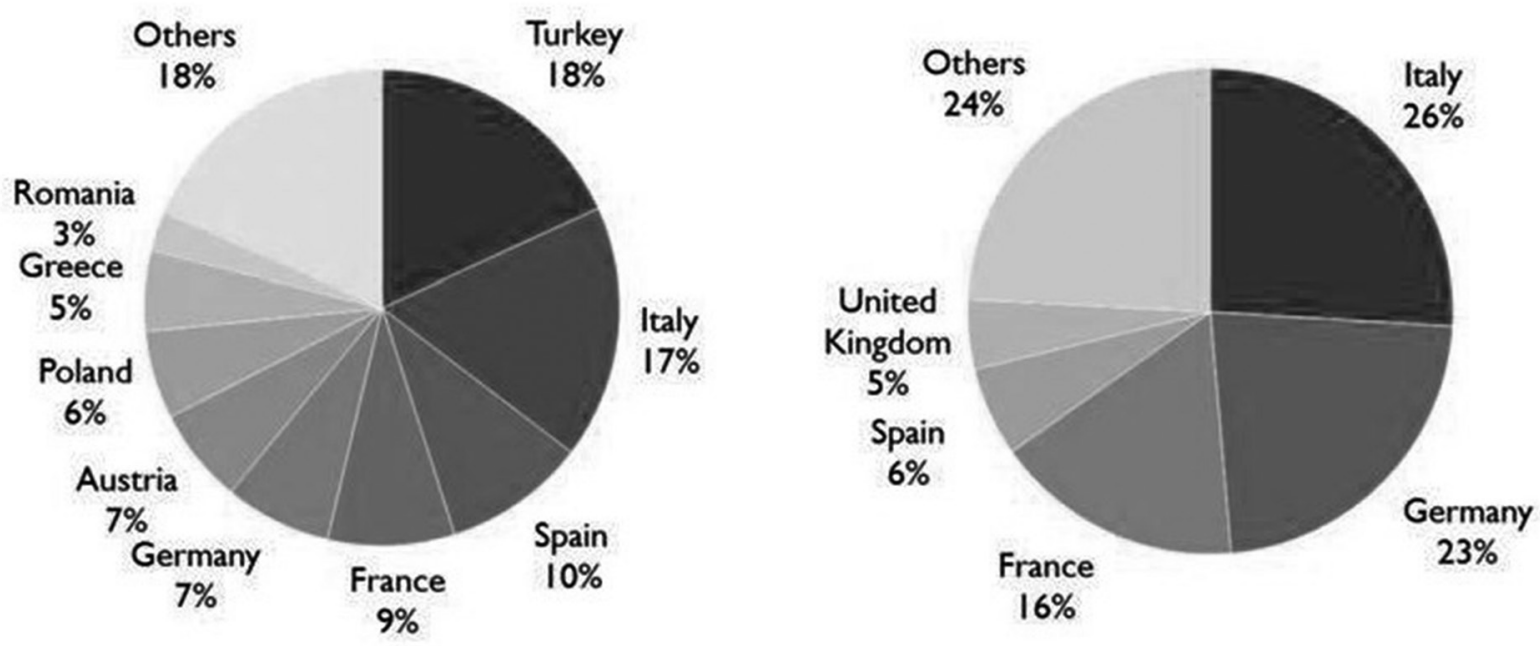

Figure 2: Europe: Distribution of organic producers (left) and processors (right) 2016 Source: FiBL-AMI survey 2018, based on national data sources and Eurostat. 
The growth of the organic sector in both European Union as well as Europe overall in 2016 was accompanied by two trends:

1. Overall double-digit growth of 11.4 percent in Europe,

2. Growth of organic farmland continued albeit at a slower pace, at 6.7 percent in Europe overall and 8.2 percent in the European Union.

In 2016, in Europe 13.5 million hectares were organic. Spain continues to be the country with the largest organic area in Europe (more than 2 million hectares), followed by Italy (1.8 million hectares) and France (1.5 million hectares).

At present, however, only 2.7 percent of the total agricultural land in Europe is organic farmland, the percentage going up to 6.7 percent in the European Union countries.

Organic retail sales in Europe were valued at 33.5 billion euros. The European Union represents the second largest single market for organic products in the world after the United States (FiBL-AMI survey, 2018).

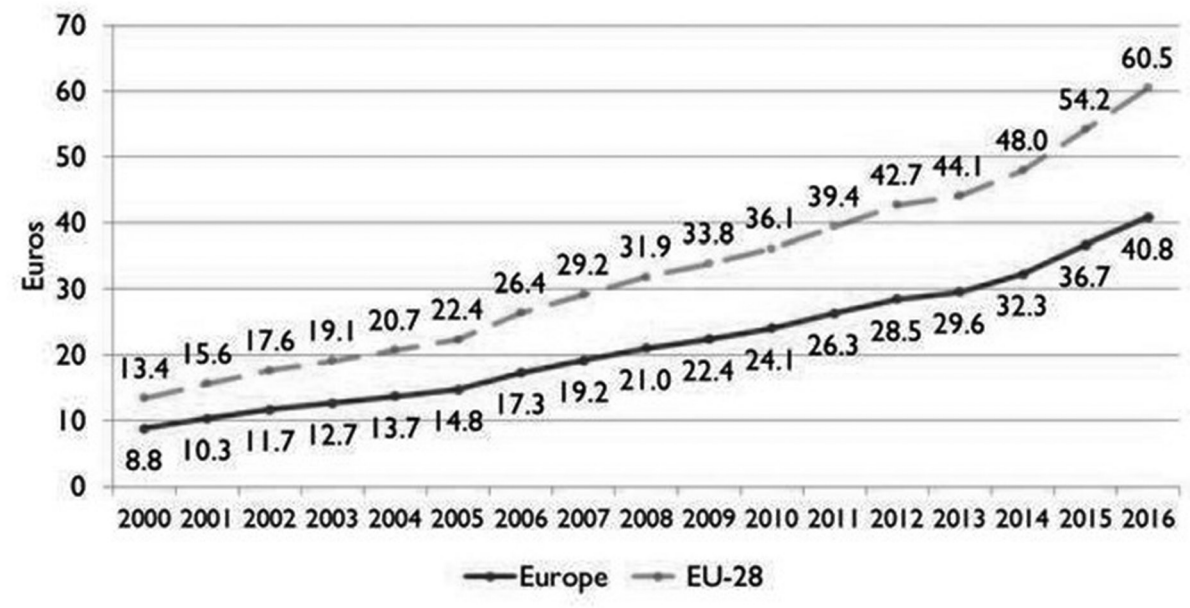

Figure 3: Europe: Growth of the per capita consumption 2000-2016

Source: FiBL-AMI survey 2018 based on national data sources

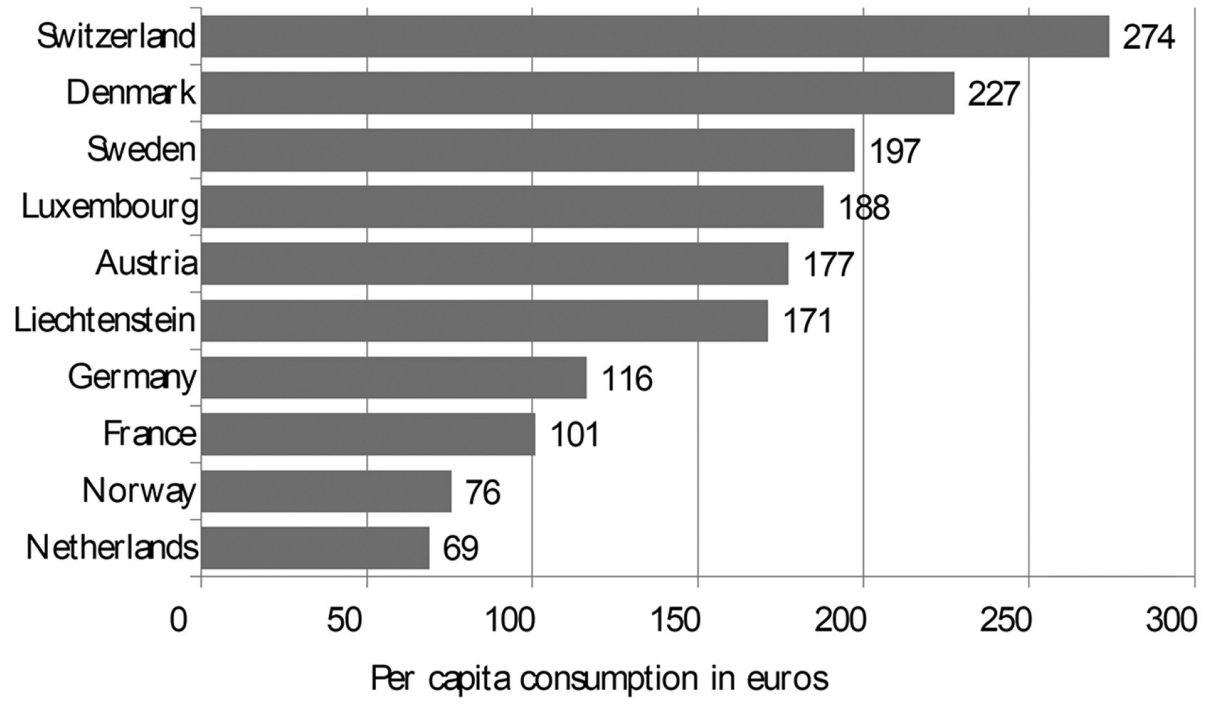

Figure 4: Europe: The countries with the highest per capita consumption 2016

Source: FiBL-AMI survey 2019 based on national data sources. 
In 2016 European consumers spent 40,8 euros on organic food per person (European Union: 60,5 euros). Per capita consumer spending on organic food has doubled in the last decade (Fig 3). The most money for organic food paid Swiss (274 euros per capita), Danes 227 euros, citizens of Sweden, Luxembourg, Austria and Lichtenstein - about 200 euro per capita.

The data analysis shows that there are still large discrepancies between European countries. Even though organic agricultural land in some countries in Central and Eastern Europe account for large shares of the overall agricultural land, consumer spending, although growing, remains low as a proportion of total spending on food in these countries (Willer et al., 2018).

\section{ORGANIC AGRICULTURE IN THE REPUBLIC OF SERBIA AND LEGISLATIVE FRAMEWORK}

Organic production started in the Republic of Serbia long before the adoption of the legislative framework. In the vicinity of Blace in 1989, the Lion foods company started its first organized organic production. The development of the non-governmental sector will start in Subotica next year with the founding assembly of the Terras Association (Simić, 2017).

Today's producers of organic products in Serbia are facing irregular and incomplete market supply of seed and planting material, insufficient quantities of biological plants for the protection of products, organic fertilizers and compost.

In 2006, the most important legal act in the field of organic production in Serbia was adopted: The Law on Organic Production and Organic Products (2006-2019). In addition, the field of organic production in the Republic of Serbia is regulated by the Rulebook on Control and Certification in Organic Production and Organic Production Methods (2011-2012), Rulebook on Documents Submitted to the Authorized Control Organization for Issuance of Certificate of Performed Control, as well as on the Conditions of Sale of Organic Products; it also lays down the conditions for the certification of organic import products, as well as the conditions and manner of sale of organic products together with products from conventional production (2010). The organic product must be recognizable and properly labeled so as not to be confused with another, conventionally produced. The Organic Production Act regulates the production of agricultural and food products obtained by organic production methods. The law targets the goals, principles and methods of organic production, the method of control, labeling and certification of organic products. The processing, storage, transport, transport, import and export of organic products, supervision of entrusted operations, and other issues of importance for organic production are particularly welcome.

The goal of the Organic Production Law is to implement organic food production methods with rational use of energy and natural resources, as well as respect for biological cycles and biodiversity, without the use of harmful chemical agents (pesticides, artificial fertilizers, growth regulators, genetically modified components).

The law defines plant production, certification of organic products, control of products and organizations that carry out control, labeling of organic products, organic product and organic production, and also determines the length of the period of conversion of conventional production to organic, as well as certification, methods of processing organic product and phases in organic production. The Act provides for severe penalties for the sale of organic products 
without certification and (or) without special labeling of the products. The bylaws to the Ordinance on the Conditions for Obtaining a Certificate or Certificate for Organic Products specify the manner in which documentation is issued The Rulebook on Technological Procedures in the Processing of Products Produced by Organic Production Methods, Cleaning Methods and Cleaning Agents for Process Lines defines the permitted ingredients, additives and auxiliary substances in food processing (2006).

In 2010 the new legal act on Organic Production was adapted. Organic production Law was focused on financing organic production in the Republic of Serbia. This law provides for the allocation of incentive funds.

According to the current legal framework, the implementation of incentive funds for the development and improvement of organic production is envisaged, from three sources:

- the budget of the Republic of Serbia,

- donation, and

- other funding sources.

Support measures can be classified into two main groups:

- Measures explicitly intended to develop and promote organic production,

- Accompanying measures for the development and improvement of organic production.

The first group of measures may include aid measures for households and other eligible beneficiaries:

- during the conversion period or during production period to ensure continuity of production on the farms,

- in the process of certification of organic production and organic products,

- in the process of education and training for organic production,

- to set up demonstration experiments in the organic production and development of the organic sector in the work of the agricultural advisory service,

- when joining.

The second group of measures (the so-called accompanying measures) are not exclusively intended for the development of organic production, but the holdings engaged in this production can use them, or indirectly benefit from them. These are measures such as:

- assistance aimed at promoting and protecting local products,

- funds for systematic control of the fertility of arable agricultural land,

- support for the export of agricultural products,

- support for the implementation of quality systems.

As a result of the implementation of incentive measures, from 2010 to 2017 there was an increase in the total area under organic production and an increase in the number of producers (Table 1).

During the four years the area under organic agriculture has increased by over $100 \%$, almost the same as the number of producers, while the number of subcontractors has quadrupled (table 2).

Largest share in organic production of agricultural products in Republic of Serbia has fruits (34\%), followed by cereals $(31 \%)$, industrial crops $(19 \%)$, forage $(10 \%)$, vegetables $(2 \%)$ and medicinal and aromatic herbs (Fig. 5) 
Table 1. Organic production in Serbia 2010-2017

\begin{tabular}{|c|c|c|c|}
\hline Year & Organic Area (ha) & Share in \%* & Organic producers \\
\hline $\mathbf{2 0 1 0}$ & $8.635,00$ & 0.17 & 137 \\
\hline $\mathbf{2 0 1 1}$ & $6.236,73$ & 0.12 & 323 \\
\hline $\mathbf{2 0 1 2}$ & $6.340,09$ & 0.13 & $1061^{* *}$ \\
\hline $\mathbf{2 0 1 3}$ & $8.228,01$ & 0.16 & $1281^{* *}$ \\
\hline $\mathbf{2 0 1 4}$ & $9.547,83$ & 0.27 & $1867^{* *}$ \\
\hline $\mathbf{2 0 1 5}$ & $15.298,00$ & 0.44 & $2289^{* *}$ \\
\hline $\mathbf{2 0 1 6}$ & $14.358,00$ & 0.41 & $2794^{* *}$ \\
\hline $\mathbf{2 0 1 7}$ & $13.423,12$ & 0.38 & $6.153^{* *}$ \\
\hline
\end{tabular}

Share of organic production in total agricultural land in Serbia

** Subcontractors involved

Source: Calculated using FiBl database https://statistics.fibl.org/europe/key-indicators

Table 2. Arable and meadows area under organic production in Serbia (2013-2017)

\begin{tabular}{|l|c|c|c|c|c|}
\cline { 2 - 6 } \multicolumn{1}{c|}{} & $\mathbf{2 0 1 3}$ & $\mathbf{2 0 1 4}$ & $\mathbf{2 0 1 5}$ & $\mathbf{2 0 1 6}$ & $\mathbf{2 0 1 7}$ \\
\hline Total area (ha) & 8227.99 & 9547.83 & $15,298.01$ & $14,357.92$ & $13,423.13$ \\
\hline Arable area (ha) & 5355.25 & 7998.47 & $13,398.19$ & $12,929.00$ & $11,874.85$ \\
\hline Meadows / pastures (ha) & 2872.74 & 1549.36 & $1,899.82$ & $1,428.92$ & $1,548.28$ \\
\hline Number of manufacturers & 259 & 291 & 334 & 390 & 434 \\
\hline Number of subcontractors & 1022 & 1575 & 1955 & 2794 & 5719 \\
\hline $\begin{array}{l}\text { Number of manufacturers } \\
\text { (with subcontractors) }\end{array}$ & 1281 & 1866 & 2289 & 3184 & 6153 \\
\hline
\end{tabular}

Source: Directorate for National Reference Laboratories, RS Ministry of Agriculture, Forestry and Water Management

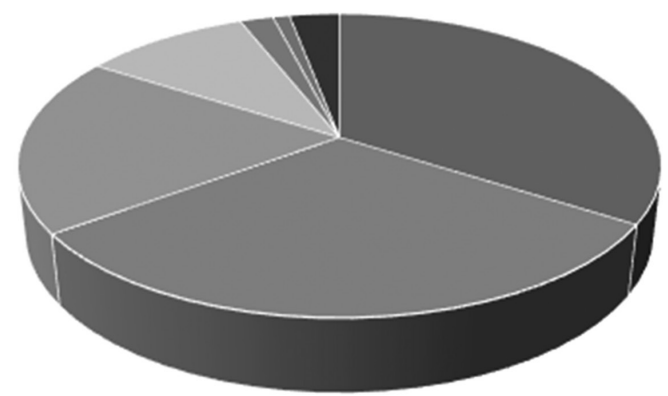

$$
\begin{aligned}
& \text { - fruits } 34 \% \\
& \text { - industrial crops } 19 \% \\
& \text { - vegetables } 2 \% \\
& \text { - other } 3 \%
\end{aligned}
$$

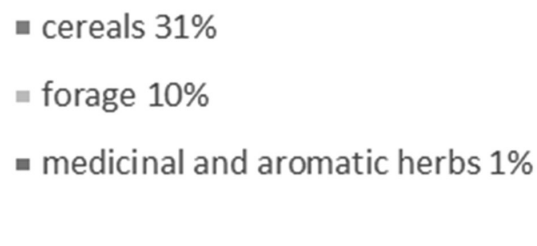

Figure 5: Structure of crops production on the territory of the Republic of Serbia in 2017.

Source: Directorate for National Reference Laboratories, Ministry of Agriculture, Forestry and Water Economy

According to statistics of the Ministry of Agriculture, Forestry and Water Economy of the Republic of Serbia, in period 2011-2018 the total area under organic production increased 3 times, while the number of producers of organically certified products doubled (table 3). 
Table 3. Structure of Organic Production in the Republic of Serbia (Source: http://www.dnrl. minpolj.gov.rs/o_nama/organska/organska_proizvodnja_u_srbiji.html)

\begin{tabular}{|c|c|c|c|c|c|c|}
\hline \multicolumn{2}{|c|}{ Description / Year } & 2013 & 2015 & 2016 & 2017 & 2018 \\
\hline \multirow{3}{*}{ Sheep } & Organic status & 2793 & 3232 & 2552 & 4665 & 5138 \\
\hline & Conversion period & 1238 & 1616 & 1826 & - & - \\
\hline & \begin{tabular}{|l|} 
Total \\
\end{tabular} & 4031 & 4848 & 4378 & 4665 & 5138 \\
\hline \multirow{3}{*}{ Pigs } & Organic status & 57 & 100 & 223 & 87 & 284 \\
\hline & Conversion period & 118 & 132 & 60 & - & - \\
\hline & Total & 175 & 232 & 283 & 87 & 284 \\
\hline \multirow{3}{*}{ Cows } & Organic status & 1853 & 2593 & 2560 & 3099 & 3594 \\
\hline & Conversion period & 323 & 153 & 335 & - & - \\
\hline & Total & 2176 & 2746 & 2895 & 3099 & 3594 \\
\hline \multirow{3}{*}{ Goats } & Organic status & 81 & 1117 & 1115 & 2048 & 1486 \\
\hline & Conversion period & 865 & 569 & 291 & - & - \\
\hline & Total & 946 & 1686 & 1406 & 2048 & 1486 \\
\hline \multirow{3}{*}{ Poultry } & Organic status & 1362 & 1079 & 3122 & 4415 & 6735 \\
\hline & Conversion period & 28 & 301 & 36 & - & - \\
\hline & Total & 1390 & 1380 & 3158 & 4415 & 6735 \\
\hline \multirow{3}{*}{ Donkeys } & Organic status & 12 & 16 & 2 & 47 & 0 \\
\hline & Conversion period & 9 & 4 & 0 & - & - \\
\hline & Total & 21 & 20 & 2 & 47 & 0 \\
\hline \multirow{3}{*}{ Horses } & Organic status & 48 & 90 & 6 & 177 & 114 \\
\hline & Conversion period & 162 & 128 & 159 & - & - \\
\hline & Total & 210 & 218 & 165 & 177 & 114 \\
\hline \multirow{3}{*}{ Bee Societies } & Organic status & 603 & 471 & 1735 & 2307 & 3061 \\
\hline & Conversion period & 1337 & 2033 & 1143 & - & - \\
\hline & Total & 1940 & 2504 & 2878 & 2307 & 3061 \\
\hline \multirow{3}{*}{ Carp } & Organic status & 0 & 0 & 0 & 0 & 0 \\
\hline & Conversion period & 655 & 0 & 0 & 0 & 0 \\
\hline & Total & 655 & 0 & 0 & 0 & 0 \\
\hline
\end{tabular}

At the moment, the primary task of agriculture in Serbia is to work on programs for the development of healthy organic food in parallel with the programs for the promotion of animal feed production. In order to encourage more intensive development of organic production in our country and to define measures and activities for overcoming obstacles to better development of organic production, in 2018, the Organic agriculture development Plan was adopted as an integral part of the National Rural Development Program (2018). Continuous harmonization of regulations in this area, one of the goals foreseen in the Plan for the development of organic production.

Organic farming requires an increase in the number of employees. Greater participation of educated workforce is needed, implementation of agro-technical measures that cost nothing but bring benefits: optimal sowing time and density, crop rotation, as well as mechanical plowing, waste recycling, water resource management, and proper selection of seed and variety material for specific locality. The fragmentation of agricultural holdings in rural areas does not constitute an obstacle to the development of organic agriculture. However, the merging of agricultural holdings into cooperatives with state direct investments and grants encourages the development of organic agriculture in Serbia (Beslać et al.,2018).

Organic agriculture is considered as a more sustainable alternative to conventional agriculture. It represents the only safe path to a transition to a green economy that leads to the advancement of the well-being of human society and social equality, with a significant reduction in environmen- 
tal risks. This means that organic farming offers solutions to reduce poverty and hunger while improving environmental performance. However, the application of organic farming requires numerous changes in the whole food chain, from producers to end consumers, as well as changes in their behavior. Considering the numerous diversities of agriculture in different countries, one single solution and model of transformation towards organic agriculture cannot be distinguished. In this path of transformation, new, modern, ecological technologies can provide significant support for the development of organic agriculture and enable it to become a world standard, not an exception. In this paper we will try to explain the role and importance of organic agriculture and its relationship with the concept of green economy (Jankovic, Jovanovic, 2018).

The experience of developed countries, which are more involved in organic production, has shown that farmers from larger estates are also beginning to engage in organic farming.

\section{MARKETING SUPPORT FOR ECO ZONE DEVELOPMENT AND ORGANIC FOOD MARKETS}

In the developed countries of the EU and the world in recent years, there is a lack of organic products due to increased market demand, but also a lack of basic agro-ecological conditions due to increased pollution of soil, water and air). Therefore, less developed countries where agro-ecosystems are still preserved are given a chance to increase their exports. Fruits and vegetables, eggs, meat and meat products, cheeses, kajmak, honey, medicinal, spicy and aromatic herbs, forest and nuts and other organic farming products are increasingly in demand in the EU market.

Serbia has significant natural potential for the development of organic agriculture and the production of quality and safe food. Geographic location, climate, land composition and other features of natural sites represent natural resources for the development of organic agriculture. The existing climatic-pedological and ecological benefits of our country provide extremely favorable conditions for the cultivation and production of the best quality health food. However, the degree of use of natural resources, primarily land, is insufficient. Out of about 4.252 million hectares of arable land, a small part is organically cultivated. Bearing in mind the areas of farms now under organic production in Serbia (Cvetković, Marić 2019)

Key partners in the marketing of organic food production are agricultural family farms, agricultural cooperatives and other similar associations, processing companies, intermediaries, companies and other institutions and organizations from the non-commercial sector, as well as individual consumers (Mitrović et al.,2019). Each partner works in the common interest, thus contributing to the development of healthy organic food production through the competences it possesses compared to the performance of other partners.

Public and private financial institutions are expected to provide financial and technological assistance to cooperatives and individual family farms, as well as marketing assistance to agricultural cooperatives, cooperatives and other associations in the development of marketing concepts and organizational structuring of marketing management (Živanović et al., 2019).

Starting from the basic idea about the possibilities of development of green economy and organic agriculture in order to produce quality health-safe food, using natural resources, it is necessary to develop projects of economic ecozones, similar to other countries in the environment (Gulič, 2019). Within them, it is necessary to define areas that meet the most stringent environmental 
standards, provide support to the local community, inform the population where the greatest development opportunities are, educate the population to prepare land for the production of health food through the application of composting.

Encouraging the development and application of biotechnology processes in the food processing and quality control and food safety in accordance with the HACCP methodology and ISO 22000 standards (Jovanović et al., 2012), raising the level of processing and finalization, as well as new ways of storing, and transporting health food are the tasks of processors - partners in the concept of marketing management.

The experience of European Union countries indicates that the biggest contribution to the growth of the organic food market comes from the chains that absorb up to 70 percent of all products belonging to this category, and then from the business sector - restaurants, schools, kindergartens, hotels, hospitals.

That is why it is needed to offer assistance to the trading companies in our country by all other partners in the field of product range, development of modern product design and packaging, distribution, storage, display and promotion of healthy organic food at the point of sale, in order to attract consumers. Specialized scientific research and educational institutions are tasked with the scientific and professional development of all partners in the development, production, marketing and quality control of health-safe organic food.

\section{CONCLUSION}

Organic farming is often proposed as a more sustainable alternative to conventional agriculture. It represents the only reliable path to a transition to a green economy that leads to the progression of the well-being of human society, with a substantial decrease in environmental risks. However, the implementation of organic farming requires many changes in the whole food chain, from producers to end consumers, as well as changes in their behavior. Taking into account the many diversities of agriculture in different countries, it is not possible to recommend a single solution and model of transformation towards organic farming.

Available data on organic farming shows that the European organic food sector is well developed. Relatively high shares of agricultural land, continual growth of the area and the number of operators, as well as a fast-growing market, show the exceptional dynamics that the organic food market and the corresponding sector has in many European countries. The organic food market is growing faster than production, and domestic supply cannot meet demand.

Although conventional production still forms the main part of the agri-food industry in all European countries, organic farming is becoming its important component. The European organic food market recorded a growth rate of $11.4 \%$. The highest growth was determined in France (22\%). In the decade 2007-2016, the value of European and EU organic food market has more than doubled. This is due not only to greater consumer awareness in environmental, health and nutrition problems, but also mainly to the fact that the industry has recognized new requirements and chances through the formation of a new, very important and profitable market sector.

Serbia has great potential for organic production. Climate, soil and natural resources provide favorable conditions for organic farming, a long tradition in food production, as well as proxim- 
ity to a large and ever-growing organic food market in the EU. The largest demand for organic products is in larger cities due to higher purchasing power. Organic product prices are up to $30 \%$ higher than conventional product prices.

Land in Serbia has been largely recovered due to reduced use of artificial fertilizers and pesticides. Isolated land parcels and livestock isolated land parcels and livestock farms can be used to produce and increase exports of health food. Organic agricultural production means fully controlled production. In order to be grounded in one area, it must meet precisely defined conditions relating to the isolation of land for organic production and processing plants from pollution sources, then the chemical and microbiological status of water, the harmonious development of plant and livestock farming production and training of experts and manufacturers with the obligation to constantly innovate knowledge. Serbia, with its natural resources and environmental conditions, as well as quality staff, still meets the above conditions. Nevertheless, organic agriculture is a marginal sector in Serbia.

Without the help of the state, this production can hardly withstand the competition of conventional production, since its economic effects are realized only after many years. It is extremely important that incentives are adequately created and tailored to the needs of the manufacturer. Producers involved in organic production have higher production costs and these higher production costs are the result of higher labor force participation on the one hand and additional control and certification costs on the one hand, and lower crop production and production.

Through an adequate marketing campaign, it is necessary to attract foreign investors who would support the development of organic agriculture in our country, especially investors from countries that import organic food. This would indirectly stimulate the growth of the organic food market and change the lifestyle of our consumers. Consumer education in this regard is the task of marketing management.

\section{REFERENCES}

Beslać M., Belokapić P., Beslać J., Finansiranje i proizvodnja organskih proizvoda u funkciji održivog privrednog razvoja, Ecologica 90 (2018), 326-330.

Cvetković A., Marić M., Značaj finansijske podrške i druge pomoći države razvoju organske poljoprivrede u Republici Srbiji, Ecologica, Vol. 26, No 94 (2019), 212-216.

Gulič A., Kriterijumi za prostorno planiranje privrednih zona u smeru razvoja zelene ekonomije u Sloveniji. Ecologica, Vol. 26, No 93 (2019), 21-25.

Janković M., Jovanović L., Organska poljoprivreda i zelena ekonomija, Ecologica, Vol. 25, No 91 (2018), 507-511.

Jovanović L., Pešić-Mikulec D., Pavlović I., Granski standardi kvaliteta i bezbednosti u prehrambenoj industriji i primarnoj proizvodnji. Ecologica, Beograd 2012, p.270.

Mitrović Lj., Mitrović A., Mitrović S., Zadruge u funkciji održivog razvoja Srbije, Ecologica, Vol. 26, No 93 (2019), 49-54.

Simić I., Organic Agriculture in Serbia at a Glance 2017, National Association Serbia Organica, 2017.

Živanović B., Cvejić A., Sikimić U., Perspektive finansiranja organskog stočarstva modelom bankarskog kredita u Republici Srbiji, Ecologica, Vol. 26, No 96 (2019), 525-534.

Willer, 2018, https://orgprints.org/34670/1/willer-etal-2018-european-statistics.pdf, accessed 11.02.2020. 
Fibl-AMI survey, 2018

IFOAM, 2019, https://www.ifoam.bio/en/news/2019/02/13/world-organic-agriculture-2019, accessed 11.02.2020

Law on Organic Production and Organic Products (Official Gazette of RS, 62/2006, 30/2010, 17/2019).

National Rural Development Program (Official Gazette of RS, 60/18).

Rulebook on control and certification, 2011-2012, Pravilnik o kontroli i sertifikaciji u organskoj proizvodnji i metodama organske proizvodnje (Official Gazette of RS, 48/2011 and 40/2012).

Rulebook on documents, 2010, Pravilnik o dokumentaciji koja se dostavlja ovlašćenoj kontrolnoj organizaciji radi izdavanja potvrde, kao i o uslovima i načinu prodaje organskih proizvoda (Official Gazette of RS, 30/10).

Rulebook on technological procedures, 2006, Pravilnik o tehnološkim postupcima u preradi proizvoda proizvedenih po metodama organske proizvodnje, metodama čišćenja i sredstvima za čišćenje tehnoloških linija, dozvoljenim sastojcima, aditivima i pomoćnim supstancama u preradi hrane (Official Gazette of RS, 62/06).

http://www.dnrl.minpolj.gov.rs/o_nama/organska/organska_proizvodnja_u_srbiji.html, accessed 11.02.2020

https://statistics.fibl.org/, accessed 11.02.2020 